\title{
Pengalaman komunikasi orang tua dengan anak yang mengalami gangguan jiwa pasca rehabilitasi di kabupaten Semarang
}

\author{
Ersha Auroryningtyas ${ }^{1}$ \\ aurory@std.unissula.ac.id \\ Made Dwi Adnjani \\ made@unissula.ac.id \\ Dian Marhaeni Kurdaningsih ${ }^{3}$ \\ marhaeni@unissula.ac.id \\ ${ }^{1,2,3}$ Prodi Ilmu Komunikasi, Fakultas Bahasa dan Komunikasi \\ Universitas Islam Sultan Agung Semarang
}

\begin{abstract}
Abstrak
Anak penderita gangguan jiwa pasca rehabilitasi seringkali ditolak oleh keluarga untuk kembali ke rumah dan di dalam kehidupan bermasyarakat tidak diakui keberadaannya. Hal ini karena stigma masyarakat yang masih menganggap anak penderita gangguan jiwa pasca rehabilitasi sebagai anak yang memiliki gangguan sehingga tidak mudah bagi orang tua untuk melakukan komunikasi bahkan enggan menerima kembali anak tersebut. Berdasarkan fenomena di atas penelitian ini dilakukan untuk mengetahui bagaimana pengalaman komunikasi orang tua dengan anak yang mengalami gangguan jiwa pasca rehabilitasi di Kabupaten Semarang. Paradigma yang digunakan adalah paradigma konstruktivis dengan metode penelitian yang digunakan adalah metode penelitian deskriptif kualitatif dengan pendekatan fenomenologi. Teknik pengumpulan data yang digunakan adalah teknik wawancara mendalam yang didukung dengan observasi dan studi pustaka. Subjek dalam penelitian ini adalah tiga informan. Dalam penelitian ini menggunakan Teori Pertukaran Kasih Sayang dan Teori Pertimbangan Sosial. Kesimpulan dari penelitian ini adalah pengalaman komunikasi orang tua dengan anak penderita gangguan jiwa pasca rehabilitasi unik dan dinamik. Hasil dari penelitian ini adalah informan I memiliki pengalaman komunikasi dengan cara komunikasi non-verbal, informan II sang anak yang dapat berbicara seperti sebelum mengalami gangguan jiwa namun mengalami penurunan kualitas komunikasi, serta anak dari informan III cara berkomunikasinya adalah dalam tindakan. Dalam penilaian sosial atau stigma negatif yang melekat di dalam masyarakat terhadap anak penderita gangguan jiwa pasca rehabiltasi dikatakan hilang atau tidak berlaku jika sang anak mampu berbaur, kembali bersosialisasi ke dalam kehidupan bermasyarakat. Keterbatasan dalam penelitian ini hanya mewawancarai orang tua yang memiliki anak penderita gangguan jiwa pasca rehabilitasi tanpa mewawancarai anak maupun masyarakat sekitar. Penelitian selanjutnya dapat dikembangkan dengan mewawancarai kedua belah pihak.
\end{abstract}

Kata Kunci: pengalaman komunikasi, gangguan jiwa, pasca rehabilitasi 


\begin{abstract}
Children with mental disorder after rehabilitation are often rejected by their family whenever they come back to their home as well as to their social life. This phenomenon can be caused by the social stigma which assumes mental disorder children who had post-rehabilitation still have mental disorder so it is not easy for their parents to communicate. They even do not want to accept their children come back. Based on the phenomenon above, the research aims to find out the communication experience among parent and children with mental disorder who had post rehabilitation in Semarang Regency. This research was conducted through constructivist paradigm with descriptive qualitative research method and phenomenology approach. The techniques of data collection were in-depth interview technique supported with observation and literature reviews. The subjects in this research were three informants. The study employed two theories, i.e. Affection Exchange and Social Judgement. The study concludes that communication experience of parents and children with mental disorder who had post rehabilitation is unique and dynamic. The results of this research were informant I had communication experience using non-verbal communication, informant II had a communication experience with the child who could speak as before he got mental disorder, but the communication quality has decreased, and informant III had the communication experience using acts. The social assessment or negative stigma which exist in society through children with mental disorder who had post rehabilitation is not valid if the children could interact and socialize throughout social life. The research is only limited to interview the parents who have children with mental disorder who had post rehabilitation and has no interview neither their children nor the society. Therefore, it is suggested the next research could be expanded by interviewing both of the children with mental disorder who had post rehabilitation or the society.
\end{abstract}

Keyword: communication experience, mental disorder, post rehabilitation

\title{
PENDAHULUAN
}

Gangguan jiwa (psikotik) di Jawa Tengah dari tahun ke tahun terus mengalami peningkatan, data yang dirilis oleh Dinas Kesehatan Provinsi Jawa Tengah mencatat, pada 2013 ditemukan 121.962 penderita gangguan jiwa, kemudian 2014 meningkat menjadi 260.247 dan pada tahun 2015 lalu menjadi 317.504 jiwa. Di Kabupaten Semarang mencapai 589 jiwa. Dari jumlah ini, 111 jiwa penderitanya merupakan anakanak. Menurut data yang didapatkan dari Dinas Sosial Kabupaten Semarang, persebaran penderita psikotik terbanyak berada di Desa Rembes, Kecamatan Bringin, dengan populasi mencapai 17 jiwa.

Berdasarkan data dari World Health Organisasi (WHO) ada sekitar 450 juta orang di dunia yang mengalami gangguan jiwa. Hasil Riset Kesehatan Dasar (Riskesdas) tahun 2013, menunjukkan bahwa prevalensi gangguan mental emosional yang ditunjukkan dengan gejala-gejala depresi dan kecemasan adalah sebesar 6\% untuk usia 15 tahun keatas atau sekitar 14 juta orang. Sedangkan, prevalensi gangguan jiwa berat, 
seperti schizophrenia adalah 1,7 per 1.000 penduduk atau sekitar 400.000 orang. (Sumber: http://www.depkes.go.id/article/print/16100700005/peran-keluarga-dukungkesehatan-jiwa-masyarakat.html, diakses pada 23 Desember 2017 pukul 20:17 WIB).

Ada beberapa faktor yang menyebabkan tingginya angka gangguan jiwa (psikotik) di Jawa Tengah, seperti tekanan keluarga, minimnya pekerjaan, pergaulan, lingkungan maupun ekonomi, faktor kelemahan hormon pada otak akibat pengaruh narkoba, ditambah lagi tata kota yang buruk, serta penyakit kronis yang diderita membuat masyarakat stres yang dapat mempengaruhi produktivitas, meningkatkan keparahan penyakit, hingga memunculkan gangguan serta sosial. Hal ini, kaitan erat dengan kesejahteraan masyarakat, khususnya tingkat kemiskinan.

Hasil penelitian yang dilakukan oleh Fajar Rinawati dan Moh Alimansur penyebab gangguan jiwa adalah biologis seperti pernah mengalami gangguan jiwa sebelumnya dan putus obat dan psikologis seperti pengalaman tidak menyenangkan dan penyebab pada aspek sosial terbanyak adalah konflik dengan keluarga dan teman.

Kementerian Kesehatan memperkirakan jumlah ODGJ yang mengalami pemasungan di seluruh Indonesia mencapai lebih 18 ribu jiwa. Proporsi keluarga yang memiliki ODGJ psikosis dan pernah melakukan pemasungan 14,3\% atau sekitar 237 keluarga dari 1.655 keluarga yang memiliki ODGJ yang dipasung dan terbanyak pada keluarga di pedesaan $(18,2 \%)$ (Riskesdas, 2013). Prosentase keluarga yang memiliki ODGJ yang dipasung di Kabupaten Semarang ini ada 12 orang dengan gangguan jiwa (ODGJ) yang terpasung. Jawa Tengah sudah mencanangkan program bebas pemasungan terhadap penduduk yang mengidap gangguan jiwa. Namun, tampaknya hingga kini program itu tak jelas arahnya. Penyebabnya, karena sebagian besar keluarga kurang memahami gangguan psikotik terutama skizofrenia. Akibatnya, penanganan yang dilakukan masih keliru seperti dipasung, dikurung, atau dikucilkan. (Sumber: Tempo.co Senin, 10 Oktober 2016 14:36 WIB/diakses pada 23 Desember 2017 pukul 20:32).

Pemerintah Kabupaten Semarang telah melakukan rehabilitasi dan pembinaan kepada penderita psikotik. Pada tahap awal penderita psikotik harus menjalani perawatan di RSJ, baik melalui perawatan intensif maupun rawat jalan. Selanjutnya pembinaan diberikan di panti rehabilitasi Balai Rehabilitasi Sosial Margo Widodo di Ungaran. Sebelum diambil oleh keluarga, biasanya penderita psikotik juga diberi keterampilan agar dapat membuka usaha dan mandiri. Namun justru masyarakat atau banyak keluarga yang enggan menerima kembali anggotanya yang psikotik. Akibatnya banyak penderita psikotik kembali labil dan menjadi gelandangan. Seperti yang diungkapkan oleh Kabid Pengelolaan Masalah Kesejahteraan Sosial Dinas Sosial Tenaga Kerja dan Transmigrasi (Dinsosnakertrans) Kabupaten Semarang, Muhtarudin "Bahkan ada juga yang sudah diambil, namun tidak diterima lagi oleh keluarga hingga mereka kembali labil dan menjadi gelandangan di jalanan."

Gangguan mental atau yang sering disebut dengan psikosis yang diklasifikasikan menjadi dua kelompok utama yaitu psikosis organic dan psikosis fungsional. Psikosis fungsional ialah gangguan mental yang berat dan sangat melibatkan seluruh kepribadian 
tanpa ada kerusakan jaringan saraf. Kategori psikosis fungsional terbagi lagi menjadi tiga kelompok yaitu, skizofrenia, gangguan bipolar dan gangguan-gangguan psikotik lain. Konsep skizofrenia ini merupakan suatu gangguan mental yang berat dengan ciriciri khasnya adalah tingkah laku aneh (bizar), pikiran-pikiran aneh, dan halusinasihalusinasi pendengaran dan penglihatan (yakni mendengar suara-suara atau melihat halhal yang tidak ada). Faktor yang menyebabkan gangguan jiwa berat (skizofrenia) ialah faktor individual meliputi struktur biologis, ansietas, kekhawatiran dan ketakutan, ketidakharmonisan dalam hidup, kehilangan arti hidup. Dan juga faktor interpersonal seperti komunikasi yang tidak efektif dan lain-lain (Sheila L, 2008 : 4).

Skizofrenia adalah suatu bentuk psikosa fungsional dengan gangguan utama pada proses pikir serta disharmoni (keretakan, perpecahan) antara proses pikir, afek atau emosi, kemauan dan psikomotor disertai distorsi kenyataan, terutama karena waham dan halusinasi, asosiasi terbagi-bagi sehingga timbul inkoherensi (Direja, 2011).

Gangguan jiwa (psikotik) terutama skizofrenia adalah bentuk gangguan jiwa yang sering dijumpai dan multifaktorial, perkembangannya dipengaruhi oleh faktor genetik dan lingkungan serta ditandai dengan gejala positif, negatif dan defisif kognitif (Jones et al, 2011). Peristiwa yang penuh stres, akan mengaktifkan aksis hipotalamus-hipofisisadrenal dan merangsang pelepasan berbagai neurotransmitter otak, terutama dopamine dan norepinefrine, kejadian ini juga dianggap sebagai faktor kunci terjadinya skizofrenia (Bobo et al, 2008).

Gejala positif meliputi waham, halusinasi, gaduh gelisah, perilaku aneh, sikap bermusuhan dan gangguan berpikir formal. Gejala negatif meliputi sulit memulai pembicaraan, afek tumpul atau datar, kurangnya motivasi dan atensi, pasif, apatis dan penarikan diri secara sosial dan rasa tidak nyaman (Videbeck, 2008). Gejala defisit kognitif meliputi gangguan dalam attention, learning and memory, dan gangguan dalam execution function, kerusakan kognitif ini sering diperburuk dengan kondisi insight yang buruk (Stuart, 2013).

Skizofrenia memberi dampak bagi kehidupan individu, keluarga menghambat pelaksanaan pekerjaan, menggangu masyarakat dan merugikan negara. Adanya individu dengan gangguan jiwa skizofrenia meningkatkan biaya dan beban ekonomi tidak hanya bagi keluarga tetapi juga negara. Asmedi (2012), mengungkapkan di Indonesia gangguan jiwa menimbulkan kerugian ekenomi mencapai Rp 20 triliun, akibat hilangnya produktivitas, beban ekonomi dan biaya perawatan kesehatan yang harus ditanggung keluarga dan negara. Pasien gangguan jiwa tidak hanya membutuhkan dukungan ekonomi saja, namun juga memerlukan sistem dukungan sosial yang mencakup dukungan emosional, informasional, instrumental dan penilaian atau penghargaan untuk menjalani pemulihan (recovery) dan menghadapi stigma di masyarakat.

Kondisi pasien yang tidak produktif dan tidak berpenghasilan menimbulkan stigma di masyarakat bahkan keluarga dan mempengaruhi stigma diri sehingga klien cenderung mengalami harga diri rendah, pendidikan rendah, tidak bekerja dan tidak ada 
penghasilan yang memberikan kontribusi menurunnya harga diri dan mempengaruhi kualitas hidup pasien (Mosanya et al, 2014).

Ketika mereka sudah menjalani rehabilitasi, justru keluarga tidak menginginkan kembali anak penderita gangguan jiwa pasca rehabilitasi karena tidak mudah bagi keluarga untuk menerimanya kembali. Stigma di dalam masyarakat yang menyebutkan jika anak yang sudah punya gangguan jiwa maka tidak mudah bagi orang tua untuk melakukan komunikasi. Hal ini, sangat dibutuhkan pendekatan para orang tua untuk menerima kembali anak yang menderita gangguan jiwa pasca melakukan rehablitasi.

Pandangan Harry Stack Sullivan yang mendedikasikan hidupnya untuk penanganan pasien skizofrenia meyakini bahwa etiologi skizofrenia berasal dari kesulitan-kesulitan interpersonal di masa awal kehidupan (terutama relasi orang tua dengan anak). Menururt Dinosetro (2008), menyatakan bahwa keluarga memiliki fungsi strategis dalam menurunkan angka kekambuhan, meningkatkan kemandirian dan taraf hidupnya serta pasien dapat beradaptasi kembali pada masyarakat dan kehidupan sosialnya.

Berdasarkan latar belakang di atas maka penulis tertarik untuk melakukan penelitian tentang "Pengalaman Komunikasi Orang Tua dengan Anak yang Mengalami Gangguan Jiwa Pasca Rehabilitasi Di Kabupaten Semarang" yang mana peran atau dukungan keluarga sangat diperlukan untuk membantu proses rehabilitasi, namun pada kenyataannya pasca melakukan rehabilitasi keluarga cenderung menolak kehadirannya kembali.

\section{Metodologi Penelitian}

Tipe penelitian ini bersifat deskriptif kualitatif dengan pendekatan fenomenologi. Fenomenologi adalah studi tentang pengalaman yang disadari (conscious experience) yaitu pengalaman komunnikasi orang tua dengan anak penderita gangguan jiwa pasca rehabilitasi yang mana disadari oleh orang tua dari sebelum menderita gangguan jiwa hingga pasca rehabilitasi.

Littlejohn (1999: 199) mendefinisikan fenomenologi sebagai studi tentang pengalaman yang datang dari kesadaran atau cara kita memahami sesuatu dengan secara sadar mengalami sesuatu tersebut. Sedangkan menurut Hegel (dalam Moustakas 1994: 26) fenomenologi mengacu pada pengalaman sebagaimana yang muncul pada kesadaran, lebih lanjut ia menjelaskan fenomenologi adalah ilmu menggambarkan apa yang seseorang terima, rasakan dan ketahui di dalam kesadaran langsungnya dan pengalamannya. Dan apa yang muncul dari kesadaran itulah yang disebut sebagai fenomena.

Fenomenologi yang digunakan adalah fenomenologi klasik atau fenomenologi transendental. Fenomenologi klasik yaitu percaya pada kebenaran hanya bisa didapatkan melalui pengarahan pengalaman, artinya hanya mempercayai suatu kebenaran dari sudut pandangnya tersendiri atau objektif. Menurut Husserl, fenomena klasik mencantumkan enam term utama dari visinya yaitu 1) intentionality, yaitu bahwa apa yang disebut sebagai kesadaran selalu merentang antara sebuah subjek terhadap objek sehingga setiap kesadaran selalu merujuk pada intense tertentu; 2) intuition, 
menjelaskan bahwa objek yang disengaja itu secara langsung terhadir "dalam" atau "dengan" permainan subjek berdasarkan intensionalitas; 3) evidence, yaitu bahwa presentasi dari objek yang dituju telah tampil sehingga diterima, dimengerti, disadari, sebagai kebenaran; 4) noesis (merupakan tindakan seseorang ketika dia memberikan rasa atau karakter terntentu seperti anda katakan, saya mengamati, mencintai, membenci, menerima atau menolak) dan noema (menjelaskan kesesuaian dengan noesis atau disebut bersifat noematic); 5) empathy (merujuk pada hal memasuki diri orang lain lalu mengalami sesuatu) dan intersubjective (keterlibatan dengan orang lain); 6) lifeworld menerangkan tentang "dunia" yang didiami orang lain sama seperti yang kita diami, dengan lifeworld memungkinkan kita dan orang terlibat secara atau intersubjective yang disebut homeworld (Sobur, 2013). Oleh karena itu Menurut Husserl, fenomenologi membimbing kita agar dapat memberikan dan memahami makna terhadap pengalaman orang lain yang bersifat intersubjektivitas.

Di dalam metodelogi penelitian yang mendasari fenomenologi mencakup empat tahap yakni bracketing (proses mengidentifikasi dengan menunda setiap keyakinan dan opini yang sudah terbentuk sebelumnya tentang fenomena yang sedang diteliti hal ini bertujuan peneliti diberi peluang untuk berusaha seobjektif mungkin dalam mengahadapi data tertentu kemudian membandingkan dengan fenomena lain yang sudah diketahui sebelumnya), intuition (terbuka untuk mengaitkan makna-makna fenomena tertentu dengan orang-orang yang telah mengalaminya, hal ini mengharuskan peneliti kreatif berhadapan dengan data yang bervariasi sampai pada tingkat tertentu memahami pengalaman baru yang muncul bahkan mengharuskan peneliti menjadi seseorang yang benar-benar tenggelam dalam fenomena tersebut), analysing (melibatkan coding terbuka, axial, dan selektif serta kategorisasi sehingga membuat sebuah pengalaman mempunyai makna yang penting dan setiap peneliti diharapkan mengalami kehidupan dengan data yang akan dideskripsikan demi merekayasa esensi pengalaman tertetu yang bermunculan), describing (menggambarkan, artinya peneliti mulai memahami dan dapat mendefinisikan fenomena menjadi "fenomenon" yaitu fenomena yang menjadi (Moustakas dalam Sobur, 2013).

\section{Pembahasan}

Pada dasarnya manusia itu tidak pernah lepas dari yang namanya komunikasi. Menurut Wilbur Schramm mengatakan bahwa "tidak mungkin tidak berkomunikasi." Di dalam keluarga, komunikasi adalah kegiatan keseharian kita. Pertukaran pasan antaranggota sebuah keluarga merupakan syarat yang diperlukan, bukan sekedar untuk mempertahankan, tetapi untuk menghidupkan keluarga. Tanpa ada komunikasi yang terjadi di dalam keluarga, maka dapat dikatakan bahwa tidak ada lagi keluarga tersebut. Melalui komunikasi, keluarga dapat membangun ikatan, membicarakan agenda, menyelesaikan masalah dan membangun masa depan.

Pengalaman komunikasi antara orang tua dengan anak penderita gangguan jiwa yang satu dengan yang lain juga berbeda, setiap orang memiliki cara sendiri untuk berkomunikasi. 


\section{Komunikasi anak sebelum mengalami gangguan jiwa}

Komunikasi interpersonal merupakan komunikasi yang terjadi secara langsung antara dua orang. Menurut Joseph DeVito Komunikasi interpersonal sebagai pengiriman pesan oleh satu orang dan penerimaan pesan oleh orang lain, atau kelompok kecil orang, dengan beberapa efek dan dengan peluang untuk mendapatkan umpan balik secara langsung (DeVito, 2002, dalam Liliweri, 2015).

Menurut Rudolp Verderber (dalam Mulyana, 2008) komunikasi antarpribadi merupakan komunikasi diadik terjadi ketika dua individu saling menerima satu sama lain sebagai titik penting dalam menanggapi perhatian dari orang lain, dan secara simultan selalu mempengaruhi dan dipengaruhi.

Pada hubungan keluarga (family relationship) merupakan salah satu contoh yang terjalin komunikasi antarpribadi yakni antara orang tua dengan anak dan tentunya komunikasi yang terjalin ini bersifat dinamik yang artinya selalu berubah-ubah setiap hari bahkan setiap jam.

Menurut Martin Buber (dalam Liliweri, 2015), komunikasi interpersonal yaitu: I - it $\rightarrow$ Manusia memperlakukan orang lain sangat impersonally, hampir seperti memperlakukan sebuah objek, tidak mengakui kehumanisan orang lain, bahkan terkadang tidak menyadari keberadaannya. I - you $\rightarrow$ Manusia mengakui sesamanya bukan sebagai objek, tetapi belum bisa membuka diri secara penuh. I - thou $\rightarrow$ Manusia mengakui sesamanya sebagai makhluk yang humanis, dan mereka saling membuka diri, bahkan kelebihan dan kekurangannya sekalipun.

Seperti yang dialami oleh informan I dan informan II, pada dasarnya anak suka bercerita apa saja kepada orang tuanya. Mulai dari kegiatan yang dilakukan pada saat di sekolah dan mengatakan apa saja yang menjadi keinginan sang anak.

Hubungan interpersonal yang terjadi antara informan I dengan anak dan informan II dengan adalah hubungan $\mathbf{i}$ - thou yang artinya informan I dan informan II memberikan kesempatan untuk sang anak diperlakukan sebagai pribadi yang memiliki ruang gerak untuk menjadi dirinya sendiri.

Berbeda dengan informan III, sang anak lebih banyak diam. Hubungan yang terjadi dengan informan III adalah i - you karena di sisi lain sang anak pun kadang terlibat pembicaraan, namun tidak dalam frekuensi yang banyak dan komunikasi dalam tindakan.

\section{Hambatan Komunikasi sebelum rehabilitasi}

Komunikasi merupakan sebuah proses penyampaian pesan dari komunikator kepada komunikan agar terjadi pengertian bersama. Proses komunikasi tidak akan berjalan apabila tidak didukung oleh berbagai elemen atau komponen komunikasi yaitu pengirim (sender), pesan (message), encoding, saluran (channel), penerima (receiver), decoding, umpan balik (feedback), gangguan atau hambatan (noise) dan konteks (context). 
Setiap elemen atau komponen dalam proses komunikasi menunjukkan kualitas komunikasi itu sendiri, masalah akan timbul apabila salah satu dari elemen komunikasi tersebut mengalami hambatan yang menyebabkan komunikasi menjadi tidak efektif.

Hambatan komunikasi dapat terjadi pada semua konteks komunikasi dan tidak bisa dihindari. Hambatan komunikasi bisa terjadi pada komunikasi antarpribadi, komunikasi kelompok, komunikasi organisasi, komunikasi massa, komunikasi antarbudaya. Hambatan komunikasi yang terjadi bisa saja dalam berbagai konteks komunikasi yang menyebabkan komunikasi menjadi tidak efektif.

Suatu konsep penting yang terdapat pada model komunikasi yang dikemukakan oleh Shannon dan Weaver adalah hambatan (noise), yakni setiap rangsangan tambahan dan tidak dikehendaki yang dapat menganggu kecermatan pesan yang disampaikan.

Hambatan (noise) yang disebutkan oleh Shannon dan Weaver (dalam Mulyana, 2008:150) terdapat dua hambatan (noise) yaitu:

1. Hambatan Psikologis

2. Hambatan Fisik

Di dalam komunikasi interpersonal sering saja terjadi hambatan dalam berkomunikasi antara individu satu dengan individu yang lain. Sama halnya yang dirasakan oleh orang tua dan anak penderita gangguan jiwa pasca rehabilitasi. Tidak mudah bagi orang tua menjalin komunikasi dengan anak penderita gangguan jiwa sebelum direhabilitasi, bahkan terkadang orang tua dengan anak yang sehat saja juga mengalami kesulitan atau hambatan komunikasi.

Hambatan komunikasi sebelum sang anak direhabilitasi, dirasakan oleh ketiga informan namun letak hambatannya yang berbeda-berbeda, namun jika dikaitkan dengan hambatan komunikasi yang dikemukakan oleh Shannon dan Weaver (dalam Mulyana, 2008:150), hambatan komunikasi yang dirasakan oleh informan I, informan II dan informan III adalah gangguan fisik dan psikologis, dua hambatan ini saling mempengaruhi satu sama lain, seperti hasil penelitian yang telah dilakukan oleh McGill University menyatakan bahwa kekerasan yang dialami di masa anak-anak secara langsung mengubah gen di otak. Gen yang bernama NR3C1 ini adalah gen yang mempengaruhi kemampuan anak untuk berhadapan dengan stres. Terganggunya kemampuan otak anak untuk memproses stres yang dialami bisa berakibat hingga jangka panjang. Anak bisa mengalami masa stres berkepanjangan ketika berhadapan dengan masalah yang bisa menuntun pada hal buruk lain seperti kecemasan, depresi hingga bunuh diri (http://psychcentral.com/news/2009/02/23/child-abuse-alters-braingene/4283.html, di akses pada 29 Juli 2018 pukul 18:20 WIB).

Hambatan yang dirasakan oleh informan I ketika ingin berbicara dengan anakanaknya mengalami kesulitan secara psikologis yaitu tatapan mata yang kosong sehingga tidak bisa untuk diajak komunikasi.

Hal ini juga dialami oleh informan II, sakitnya dalam psikis mempengaruhi anak dalam komunikasi (gangguan pada komunikasi), berbicara tidak jelas bahkan tidak ada jawaban ketika ditanya oleh orang tua maupun anggota keluarga lainnya.

Informan III, tidak mengalami hambatan yang signifikan karena pada dasarnya sang anak pendiam, ketika mengalami gangguan jiwa komunikasinya benar-benar 
terputus karena rasa sakit hatinya yang lebih besar maka ia terkunci dalam diam sehingga membuatnya lupa akan banyak hal.

Dalam hambatan komunikasi yang dirasakan informan I, informan II dan informan III adalah hambatan komunikasi yang disebabkan oleh personal limitations yaitu keterbatasan fisik dan mental yang menghambat pencapaian pengertian bersama yang mana sang anak mengalami kesulitan berkomunikasi karena dirinya terganggu, sebagai akibatnya maka komunikasi dengan orang lain pun terganggu.

\section{Komunikasi anak saat proses rehabilitasi}

Pada individu yang 'neorotik', bagian-bagian dalam dirinya yang disebut tidak sadar atau mengalami tekanan, atau ditolak pada kesadaran menjadi terhambat sehingga bagian-bagian tidak mengomunikasikan dirinya kealam sadar atau tidak dapat mengelola bagian dalam diri individu tersebut.

Komunikasi merupakan sebuah seni berbicara yang sifatnya dinamik. Pengalaman komunikasi setiap orang tentu juga berbeda-beda, seperti dalam proses rehabilitasi. Dalam hal ini, komunikasi yang digunakan adalah komunikasi terapeutik (therapeutic communication) yaitu terapis mengarahkan komunikasi sehingga pasien dihadapkan pada situasi dan pertukaran pesan yang dapat menimbulkan hubungan sosial yang bermanfaat.

Menurut As Hornby (1974) terapeutik merupakan kata sifat yang dihubungakan dengan seni dari penyembuhan, dapat diartikan bahwa komunikasi terapeutik adalah komunikasi yang direncanakan secara sadar, tujuan dan kegiatannya difokuskan untuk penyembuhan klien.

Tugas psikoterapi adalah membantu orang tersebut untuk mencapai dan menjalin hubungan khusus dengan terapis agar komunikasi yang baik dapat muncul dengan dirinya. Ketika hal ini tercapai, maka sang anak yang menjalanii rehabilitasi dapat berkomunikasi dengan baik di dalam diri maupun dengan orang lain.

Dalam hal ini, peneliti tidak membahas jauh tentang komunikasi terapeutik, melainkan komunikasi yang terjadi antara orang tua dengan anak penderita gangguan jiwa pasca rehabilitasi pada saat menjalani rehabilitasi.

Adanya perubahan komunikasi anak sebelum mengalami gangguan jiwa dan komunikasi anak saat menjalani proses rehabilitasi. Sudah dibahas pada point 4.1.1 yaitu hubungan interpersonal informan I dengan sang anak adalah $\mathbf{i}$ - thou sebelum mengalami gangguan jiwa, namun berubah ketika anak mengalami gangguan jiwa dan menjalani rehabilitasi.

Hubungan interpersonal yang terjadi antara informan I dengan sang anak tidaklah $\mathbf{i}$ - thou melainkan $\mathbf{i}$ - it yaitu orang lain diperlakukan sebagai obyek untuk memenuhi kebutuhan dan keinginan "Aku".

Namun tidak terjadi dengan informan II, hanya saja untuk kualitas komunikasi yang terjadi antara informan I dan informan II dengan anak mengalami penurunan kualitas interaksi. Berbeda dengan informan III yang memang pada dasarnya pendiam, berbicara hanya seperlunya saja dan lebih banyak dalam tindakan serta tidak menjalani rehabilitasi maka hubungan komunikasi dengan informan III tidak ada perubahan. 


\section{Komunikasi anak pasca rehabilitasi}

Hubungan antarpribadi diprakarsai dan dipelihara melalui pertukaran perilakuperilaku kasih sayang seperti memeluk, berciuman, pegangan tangan atau dengan komunikasi verbal "Aku sayang kepadamu."

Komunikasi kasih sayang berkontibusi tidak hanya kepada kesehatan tentang hubungan, tetapi juga kepada kesehatan orang itu sendiri, menerima perilaku dengan penuh kasih sayang (termasuk sentuhan dengan penuh kasih sayang) adalah bermanfaat bagi kesehatan fisik dan mental. hal ini dikemukakan oleh Kory Flyod, Jeff Judd dan Colin Hesse (2008) dengan judul Affection Exchange Theory (dalam Budyatna, 2015:301).

Di dalam model ini, Floyd dan Morman (1998) menambah penjelasan konseptual dengan membedakan tiga bentuk penampilan kasih sayang, yaitu:

1. Komunikasi Verbal

Dalam wawancara dan observasi ketika di lapangan, ketiga informan yang terdiri dari informan I, informan II, informan III kurang lebihnya mengatakan bahwa "Apapun kondisinya, yang namanya anak adalah titipan. Dan mereka sangat berarti bagiku."

2. Komunikasi Non-verbal langsung

Dalam observasi ketika peneliti mewawancarai informan I, sedikit memberikan belaian lembut di kepala sang anak yang mendapatkan perawatan dipasung.

3. Komunikasi Non-verbal tidak langsung

Perilaku-perilaku ini juga dilakukan oleh ketiga informan yang selalu memberikan dukungan yang bersifat psikologis, sosial bahkan materiel. Dalam hasil wawancara dengan ketiga informan yakni informan I, informan II dan informan III memberikan dukungan psikologi seperti yang dilakukan oleh informan I yaitu salah satu anaknya yang tidak dipasung diberikan kebebasan untuk jalan-jalan dan dukungan materiel yang mana informan I dan informan III menjadi orang tua tunggal sehingga harus bekerja untuk memenuhi kebutuhan pokok untuk keluarganya, sedangkan informan II memberikan perlakuan apapun yang diminta oleh sang anak dituruti.

Hubungan antarpribadi dapat berkembang atau mengalami penurunan kualitas interaksi. Hasil dari analisis terhadap komunikasi orang tua terhadap anak pasca rehabilitasi, hal ini dapat terjadi karena adanya perubahan dari psikis sang anak pasca rehabilitasi. Perlu waktu untuk mengembalikan anak seperti semula.

Pada dasarnya semua orang bisa berkomunikasi, termasuk anak penderita gangguan jiwa pasca rehabilitasi, hanya saja cara komunikasinya yang berbeda. Kita yang mencoba untuk memahami dan mengerti apa yang ia ungkapkan, apa yang dia inginkan.

Di dalam komunikasi terdapat jenis komunikasi verbal dan non-verbal, seperti yang di kemukakan oleh Dr. Arni Muhammad (2009:4), membagi 
komunikasi ke dalam dua jenis, yaitu komunikasi verbal dan komunikasi non-verbal.

Komunikasi verbal dan komunikasi non-verbal, keduanya sangat melengkapi satu sama lain. Komunikasi menggunakan simbol dalam bentuk kata-kata yang diucapkan atau dituliskan. Komunikasi verbal sering disamakan dengan istilah"bahasa." Sedangkan komunikasi non-verbal adalah semua rangsangan (kecuali verbal) dalam suatu suatu setting komunikasi yang dihasilkan individu dan penggunaan lingkungan oleh individu yang mempunyai nilai pesan potensial bagi pengirim atau penerima. Biasanya dikenal dengan bahasa tubuh atau gerak tubuh.

Dalam kasus informan I, kedua anaknya mengalami gangguan jiwa hanya saja perkembangan pada masing-masing kakak-adik ini berbeda. Koiruddin yang saat ini masih menjalani perawatan atau treatment dengan cara dipasung, cara berkomunikasi yang dilakukan dengan informan I terhadap sang anak menggunakan komunikasi satu arah dan non-verbal sedangkan Turhamim, sudah bisa berinteraksi dua arah dan menggunakan komunikasi verbal, temuan penelitian ini didukung dengan pernyataan informan I "dia bisa diajak berbicara, ketika di jalan bertemu orang dan disapa maka dia akan menjawab." hanya saja tidak dalam keramaian.

Fungsi dari komunikasi non-verbal adalah Perilaku nonverbal dapat mengulangi perilaku verbal, contohnya ketika informan I memberikan makan kepada Koiruddin, informan mengatakan verbal "makan dulu" diikuti komunikasi non-verbal yaitu memberikan piring yang berisi makanan dan diberikan oleh Koiruddin.

Hal ini juga serupa dengan informan III, yang mana sang anak tidak mengomunikasikan segala sesuatunya dengan verbal, namun lebih banyak non-verbal, contohnya ketika peneliti observasi, sang anak sedang membakar tempurung, pendamping saya bertanya "sedang apa, Him?" dia hanya menjawab dengan non-verbal yaitu gerak tubuh yakni menunjukan tangannya ke arah pekerjaan yang sedang dilakukan.

Berbeda dengan informan II, sang anak sudah bisa berinteraksi dua arah baik dengan verbal maupun non-verbal.

\section{Penilaian Sosial Terhadap Anak Penderita Gangguan Jiwa Pasca Rehabilitasi}

Stigma di dalam masyarakat yang menyebutkan jika anak yang sudah punya gangguan jiwa maka tidak mudah bagi orang tua untuk melakukan komunikasi bahkan masih banyak yang menganggap "gila" bagi penderita gangguan jiwa meski telah menjalani rehabilitasi. Ketika mereka sudah menjalani rehabilitasi, justru keluarga tidak menginginkan kembali anak penderita gangguan jiwa pasca rehabilitasi karena tidak mudah bagi keluarga untuk menerimanya kembali.

Berdasarkan hasil observasi langsung yang dilakukan peneliti dan hasil wawancara dengan informan terlihat bahwa masyarakat sekitar sudah menerima anak penderita gangguan jiwa pasca rehabilitasi dan bagi masyarakat sekitar adalah ketika anak penderita gangguan jiwa pasca rehabilitasi sudah mau berbaur dengan masyarakat kembali maka stigma negatif terhadap anak penderita gangguan jiwa pasca rehabilitasi hilang. 
Informan I mengatakan bahwa warga di sekitar rumah sudah mengetahui apa yang dialami oleh anak dari informan I sehingga mereka memaklumi, bahkan jika bertemu di jalan warga yang berinisiatif untuk menyapa salah satu anak dari informan I, namun terkadang masih mendapatkan perlakuan yang kurang mengenakan hati, yakni menjadi bahan olokan anak-anak.

Namun sedikit berbeda yang dialami oleh informan II, bahwa sempat mendapat perlakuan tidak menyenangkan, kurang dipahami bahkan mendapatkan perlakuan kasar dari keluarga hanya karena ada salah satu tetangga yang mengadu ke informan II bahwa sang anak telah merusak halaman rumahnya, informan II main hakim sendiri sedangkan sang anak berusaha untuk menyampaikan apa yang sebenarnya terjadi. Artinya keluarga kurang memahami dari segi sang anak, kurang memberikan rasa percaya terhadap anak.

Informan III mendapat penilaian sosial terhadap sang anak yaitu hal yang menakutkan jika didekati, padahal tidak menjadi sebuah masalah besar jika mendekati anak penderita gangguan jiwa pasca rehabilitasi. Hanya saja kita yang harus memaklumi mereka, tidak sebaliknya yang mereka harus mengerti kita. Pendekatan yang dilakukan adalah dengan pendekatan yang halus, tidak memaksa bahkan tidak dalam keadaan ramai.

Pada penelitian ini peneliti akan menjelaskan mengenai penilaian sosial atau social judgement yang mempelajari tentang proses psikologis yang mendasari pernyataan sikap dan perubahan sikap seseorang melalui pertimbangan dan komunikasi terhadap objek sosial dan isu tertentu merupakan hasil proses pertimbangan (judgement) yang terjadi dalam diri orang tersebut terhadap pokok persoalan yang dihadapi.

Secara ringkas menjelaskan bahwa perubahan sikap seseorang terhadap stigma dan penilaian sosial masyarakat terhadap anak penderita gangguan jiwa pasca rehabilitasi merupakan hasil proses pertimbangan (judgement) yang terjadi dalam diri orang tersebut terhadap pokok persoalan yang dihadapi.

Proses "mempertimbangkan" stigma dan penilaian sosial masyarakat terhadap anak penderita gangguan jiwa pasca rehabilitasi menurut Sherif (1967) berpatokan pada kerangka rujukan (reference points) yang dimiliki seseorang. Kerangka rujukan inilah yang pada gilirannya menjadi "jangkar" untuk menentukan bagaimana seseorang memposisikan suatu pesan persuasif yang diterimanya.

Hal ini dapat menggambarkan pertimbangan sosial masyarakat menurut informan yang memiliki anak penderita gangguan jiwa pasca rehabilitasi. Untuk lebih jelasnya, berikut gambar yang menerangkan proses bagaimana perimbangan itu bisa terjadi. 


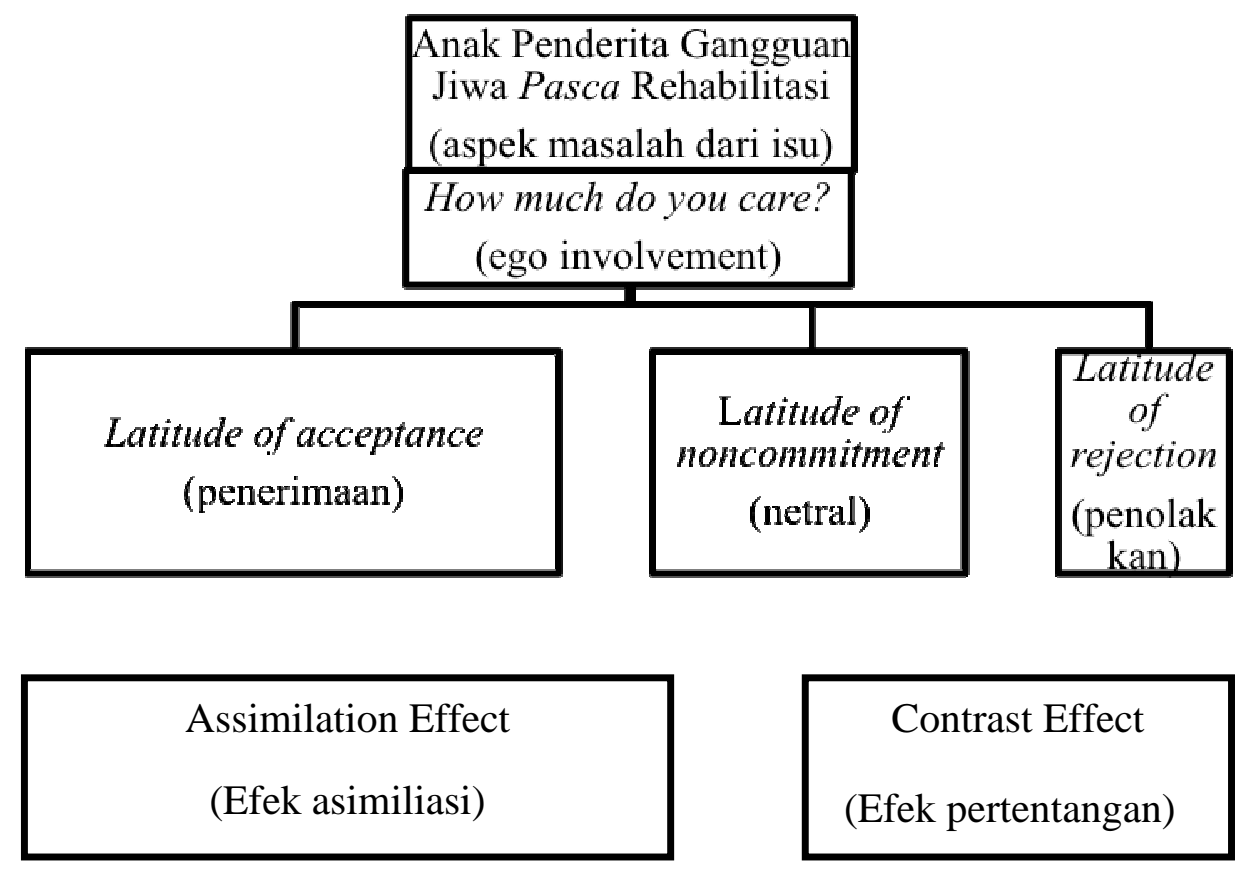

\section{Gambar 2.2 Hasil social judgement Informan terhadap anak penderita gangguan jiwa pasca rehabilitasi}

Latititude of acceptance atau penerimaan lebih besar dari sikap netral dan penolakkan, hal ini terjadi karena masyarakat sekitar memahami kondisi anak penderita gangguan jiwa pasca rehabilitasi, dan mereka menganggap jika sang anak penderita gangguan jiwa pasca rehabilitasi sudah mau ikut berbaur dengan masyarakat atau kembali kedalam kehidupan bermasyarakat maka dianggap tidak mengalami gangguan jiwa atau sudah sembuh, hal ini disampaikan oleh pendamping peneliti yang sekaligus penggerak yayasan rehabilitasi di Desa Rembes, Kabupaten Semarang.

Latitude of noncommitment atau netral, sikap masyarakat yang tidak menerima dan juga tidak menolak artinya masyarakat bersikap netral. Sikap ini tidak sebesar menerima.

Latitude of rejection atau penolakkan, sikap masyarakat ini masih ada namun tidak sebesar latitude of acceptance dan latitude of noncommitment. Hal ini masih ditemukan di dalam kehidupan masyarakat yang masih memandang sebelah mata bahwa anak penderita gangguan jiwa pasca rehabilitasi tidak bisa melakukan apa saja bahkan bekerja, karena stigma negatif masyarakat masih begitu melekat, seperti yang dirasakan oleh informan I yang masih mendapat perlakuan kurang menyenangkan yakni pernah diolok-olok oleh anak-anak kecil, hal ini juga dirasakan oleh informan II yang masih mendapat perlakuan kurang baik oleh tetangganya yang mana anak dari informan II pernah mendapat perlakuan kurang menyenangkan yang disebabkan bukan karena ulahnya. Informan III pun juga merasakan bahwa sang anak menakutkan bagi masyarakat, hal ini karena kurang pahamnya kita untuk memahami mereka.

Ukuran social judgement menghasilkan sikap penerimaan, netral dan penolakkan karena dipengaruhi oleh ego-involevement yakni derajat yang menunjukkan arti penting suatu isu bagi seseorang. Stimulus (ego-involvement) akan turut menentukan sejauhmana seseorang 
dapat dipengaruhi. Dengan kata lain makin berarti suatu isu bagi seseorang maka semakin kecil kemungkinan orang tersebut dapat dipengaruhi.

Dalam proses mempertimbangkan menimbulkan dua efek yaitu efek asimilasi dan efek kontras. Efek asimilasi cenderung dapat bisa diterima daripada keadaan yang sebenarnya. Masyarakat yang menjadi sasaran persuasi akan menilai pesan atau pernyataan tersebut tampak sejalan dengan patokannya. Sedangkan pernyataan yang berada dalam rentang penolakan akan tampak semakin berbeda karena memperbesar perbedaan dan pada akhirnya pesan dapat ditolak dengan mudah oleh masyarakat.

Dalam mempertimbangkan sosial terdapat proses psikologis di dalamnya, yang mendasari pernyataan sikap dan perubahan sikap melalui komunikasi. Asumsi dasarnya bahwa dalam menilai sesuatu, manusia membuat deskripsi dan kategorisasi khusus. Dalam kategorisasi manusia melakukan perbandingan-perbandingan diantara berbagai alternatif yang disusun oleh individu untuk menilai stimulus-stimulus yang datang dari luar. Teori ini mengemukakan bahwa seseorang mengetahui apa sikapnya dan mampu menentukan perubahan sikap apa yang akan diterimanya serta perubahan apa yang akan ditolaknya.

Pernyataan diterima atau ditolak itu didasarkan atas peta kognitif kita sendiri terhadap pandangan anak penderita gangguan jiwa pasca rehabilitasi. Seseorang menerima atau menolak suatu pernyataan, bergantung kepada keterlibatan egonya sendiri. Ketika orang menerima, mereka dengan segera men-judge (memperkirakan, menilai) di mana anak penderita gangguan jiwa pasca rehabilitasi harus ditempatkan dalam bagian otaknya dengan cara memperlakukan yang diterimanya selama ini.

\section{Kesimpulan}

Berdasarkan hasil analisis yang dilakukan peneliti terhadap ketiga informan terkait pengalaman komunikasi orang tua dengan anak penderita gangguan jiwa pasca rehabilitasi, dapat disimpulkan bahwa:

1. Pengalaman komunikasi orang tua dengan anak penderita gangguan jiwa pasca rehabilitasi unik dan dinamik. Pada dasarnya setiap anak dapat diajak berkomunikasi, hanya saja kemampuan komunikasi anak berbeda-beda seperti salah satu anak dari informan I menggunakan komunikasi non-verbal yaitu komunikasi dengan menggerakkan anggota tubuh atau bahasa tubuh. Berbeda dengan informan II, sang anak yang dapat berbicara seperti sebelum mengalami gangguan jiwa namun mengalami penurunan kualitas komunikasi. Begitu juga dengan informan III, cara berkomunikasinya adalah dalam tindakan atau actions, namun sedikit berbeda ketika anak dari informan III berkomunikasi dengan teman yang kondisinya sama dengannya, ia berkomunikasi dengan menggunakan bahasa mereka yang didukung dengan komunikasi non-verbal yaitu senyuman, gerakan anggota tubuh dan gerakan kepala seperti anggukan yang menandakan bahwa salah satu dari mereka memahami komunikasi yang terjadi.

2. Penilaian sosial masyarakat terhadap anak penderita gangguan jiwa pasca rehabilitasi masih ada sikap penolakan. Stigma yang masih melekat dalam kehidupan masyarakat anak-anak tersebut tetap dianggap mengalami gangguan kejiwaan meski telah menjalani masa rehabilitasi, bahkan tidak bisa melakukan apa saja atau tidak dapat bekerja, pada kenyataannya mereka bisa bekerja sesuai dengan yang mereka inginkan. 


\begin{abstract}
Alasan mereka dianjurkan untuk bekerja adalah agar tidak ada celah untuk berpikir bahwa dia pernah sakit, atau bahasa mudahnya adalah memberikan dia kesibukan agar tidak ingat apa yang menimpa dirinya. Stigma negatif ini akan hilang atau tidak berlaku jika sang anak penderita gangguan jiwa pasca rehabilitasi mampu berbaur dan kembali bersosialisasi ke dalam kehidupan bermasyarakat.
\end{abstract}

\title{
Daftar Pustaka
}

\section{Buku}

Ardianto, Elvinaro \& Bambang Q-Anees. (2007). Filsafat Ilmu Komunikasi. Bandung: Simbiosa Rekatama Media.

Arif, Iman Setiadi. (2006). Skizofrenia Memahami Dinamika Keluarga Pasien. Bandung: PT Refika Aditama.

Budyatna, Muhammad. (2015). Teori-Teori Mengenai Komunikasi Antarpribadi. Jakarta: Prenadamedia Group.

Bungin, Burhan. (2011). Penelitian Kualitatif. Jakarta: Kencana Predana Media.

Liliweri, Alo. (2015). Komunikasi Antar-Personal. Jakarta: Kencana Prenadamedia Group

Littlejohn, Stephen W \& Karen A. Foss. (2009). Teori Komunikasi, edisi 9. Jakarta: Salemba Humanika.

Morissan. (2013). Teori Komunikasi:Individu Hingga Massa. Jakarta: Prenadamedia Group.

Mubarok, \& Adnjani, M. D. (2014). Komunikasi Antarpribadi Dalam Masyarakat Majemuk. Jakarta Timur: Dapur Buku.

Mulyana, Deddy. (2008). ILMU KOMUNIKASI Suatu Pengantar. Jakarta: PT Remaja Rosdakarya.

Sobur, Alex. (2014). Filsafat Komunikasi Tradisi dan Metode Fenomenologi. Bandung: PT Remaja Rosdakarya.

\section{Jurnal}

O.Hasbiansyah. (2008). Pendekatan Fenomenologi:Pengantar Praktik Penelitian Dalam Ilmu Sosial Dan Komunikasi. MEDIATOR, 163-180.

Prianti, D. D. (2011). STUDI FENOMENOLOGI TENTANG PENGALAMAN KOMUNIKASI ANTAR PRIBADI ORANG TUA-ANAK TERHADAP PEMAHAMAN ANAK PADA NORMA-NORMA PERILAKU (KASUS PADA ANAK PENYANDANG AUTISME). MAKNA, 2, 1-8.

Retnowati, Y. (2008). Pola Komunikasi Orang Tua Tunggal dalam Membentuk Kemandirian Anak (Kasus Di Yogyakarta). Ilmu Komunikasi, 6, 199-211.

\section{Skripsi}

Fatimah. (2017). Kecemasan Komunikasi Dalam Proses Penyusunan Skripsi Pada Mahasiswa Tingkat Akhir Universitas Islam Sultan Agung Semarang. Skripsi. Fakultas Bahasa Dan Ilmu Komunikasi. Semarang: Universitas Islam Sultan Agung.

Gusti, Dara Gusta. (2017). Pengalaman Komunikasi Antar Pribadi Long Distance Marriage (Studi Fenomenologi Dalam Membangun Keterbukaan Diri Pada Pasangan). Skripsi. Fakultas Bahasa Dan Ilmu Komunikasi. Semarang: Universitas Islam Sultan Agung. 
Kinanti, Laksmita Nawang. (2017). Pengalaman Komunikasi Antar Pribadi Dalam Membangun Romantic Relationship Pada Pasangan Suami Istri Dengan Status Mahasiswa. Skripsi. Fakultas Bahasa Dan Ilmu Komunikasi. Semarang: Universitas Islam Sultan Agung.

\section{Sumber Internet}

http://desidwiprianti.lecture.ub.ac.id/author/desidwip/ diakses pada 22 Desember 2017 pukul 18:25 WIB

http://www.depkes.go.id/article/print/16100700005/peran-keluarga-dukung-kesehatan-jiwamasyarakat.html, diakses pada 23 Desember 2017 pukul 20:17 WIB

Tempo.co Senin, 10 Oktober 2016 14:36 WIB/diakses pada 23 Desember 2017 pukul 20:32

https://pijarpsikologi.org/tahukah-anda-fisik-saling-memperngaruhi/diakses pada 29 Juli 2018 pukul 18:20 WIB 